Contents List available at VOLKSON PRESS
Multidisciplinary Inclusive Education, Management
and Legal Services (MIEMLS)
Journal Homepage: https://topicsonsocialdevelop.com
DOI: $10.26480 /$ ismiemls. 01.2018 .21 .22

\title{
ANALYSIS OF CONVENTION CONCERNING THE PROTECTION OF THE WORLD CULTURAL AND NATURAL HERITAGE
}

\author{
Jing Changhao \\ Department of Law, Wuhan University of Technology Luo Shi Road, Wuhan, China \\ *Corresponding Author Email: 373546952@qq.com
}

This is an open access article distributed under the Creative Commons Attribution License, which permits unrestricted use, distribution, and reproduction in any medium, provided the original work is properly cited.

\section{ARTICLE DETAILS}

\section{Article History:}

Received 26 June 2018 Accepted 2 July 2018

Available online 1 August 2018

\begin{abstract}
Due to the increasing natural transformation process, over-expanded urbanization and tourism, and the construction of large-scale public or private projects, many world cultural heritages are under serious threat. The idea that the world cultural heritage is regarded as the common heritage of mankind has always been valued by the world in the process of globalization. The protection of the world cultural heritage is not only the responsibility of a country, but also the collective responsibility of the international community. Therefore, it needs to be protected through international law. The measures stipulate the problems and shortcomings in the practice of protecting cultural heritage in the world. In 1972, UNESCO established the concept and content of protection of the world cultural heritage in the Convention Concerning the Protection of the World Cultural and Natural Heritage. It has a landmark significance for the protection of the common cultural heritage of mankind. Therefore, it is necessary to briefly analyze Convention Concerning the Protection of the World Cultural and Natural Heritage.
\end{abstract}

\section{KEYWORDS}

World Cultural Heritage, International Convention, Protection.

\section{INTRODUCTION}

In the course of recent developments, the protection of international cultural heritage has gradually evolved from the first principle-oriented provisions to a relatively mature, practically-preservative protection mechanism. It has contributed to the development and expansion of international cooperation forces and urged the controversy over the protection of cultural heritage [1]. To prevent cultural heritage from being further damaged and play its due role. At the same time, it also reflects that the international law on the protection of the world's cultural heritage is moving toward diversification of protection concepts, the hardening of supporting protection measures, and the further development of the implementation of a scientific protection mechanism.

\subsection{Background}

The concept of the world's cultural heritage has gone through a gradual process from its emergence to its development from its birth to its development. From the initial conception to conception, the concept has gradually become clear and clear, and the nations, international organizations, and other entities have made arduous and unremitting efforts. To enrich the connotation and protection scope of cultural heritage and gradually form a concept known to the world and universally accepted.

At the beginning of the 20th century, the League of Nations took the lead in establishing the concept of protecting the world's cultural heritage. Under the prevailing conditions, the organization hoped to adopt international cooperation to protect the common heritage of mankind worldwide. Such a formulation can be called a new trend that has inspired the idea of cultural heritage protection. Until 1948, UNESCO promoted the implementation of an international cooperative action. The action was organized in response to the protection of the unmovable cultural heritage, and the collective protection of cultural heritage originated there led to follow-up actions [2]. A breakthrough has been achieved in the collective protection of cultural heritage activities implemented in the international community, and the concept of heritage protection promoted by many countries and international organizations has been put into practice.

In 1959, the temple of Abu Simbel in Egypt, due to the construction of the Aswan Dam, caused the water level of the river basin to increase and it was in danger of being submerged. In the fight between Egypt and the Sudan, UNESCO called on the international community to cooperate in order to promote a large-scale protection operation for the temple. The temple can be properly and completely cut and rebuilt. In the tense and orderly cooperation of the rescue of Egypt's prominent Pharaoh Ramses Temple, many countries participating in international cooperative actions have become aware of the friendly cooperation between countries and jointly safeguard the necessity and possibility of action [3]. It is precisely with the participation of experts, scholars, and technicians from various countries around the world that the problems in the maintenance process have been solved. In the following period, many international joint protection actions have been promoted, and many cultural heritage resources have been preserved.

Continuation, so far these actions are relished by people. This case is a classic case in the history of the protection of the world's cultural heritage. There are still many experiences worth promoting today. The international community has also gradually realized that the establishment of the status of the world cultural heritage in the form of international conventions and the forms of international cooperation have the necessary realistic conditions. Therefore, the formulation of the Convention Concerning the Protection of the World Cultural and Natural Heritage Convention (hereinafter referred to as the "Convention") was put on the agenda by UNESCO, which was promulgated in 1972 and came into effect on December 17, 1975. Since then, the protection of world cultural heritage has entered a phase of rapid development. Four years later, UNESCO established the World Heritage Committee as a convention 
management agency and set up a World Heritage List on World Heritage projects. As long as the statement is listed on the World Heritage List of historic sites and monuments, it can receive appropriate financial assistance through the World Heritage Fund, and it can also guide tourists from various countries to conduct tourism and sightseeing activities through the management department [4]. As of May 28, 2018, there were 1,073 World Cultural Heritage sites registered on the World Heritage List. In the course of recent developments, the protection of international cultural heritage has gradually evolved from the first principle-oriented provisions to a relatively mature, practically-preservative protection mechanism. It has contributed to the development and expansion of international cooperation forces and urged the controversy over the protection of cultural heritage. To prevent cultural heritage from being further damaged and play its due role. At the same time, it also reflects that the international law on the protection of the world's cultural heritage is moving toward diversification of protection concepts, the hardening of supporting protection measures, and the further development of the implementation of a scientific protection mechanism.

\section{PURPOSE OF THE WORLD HERITAGE CONVENTION}

In the preamble, the Convention elaborated that the world's cultural heritage is threatened with various forms of destruction and loss. These threats are mainly attributed to the improvement of economic and social conditions that have caused the deterioration of many long-lost cultural heritage sites, even on the verge of adversity. Lost situation. If the loss of the world's cultural heritage is based on the serious consequences of the depletion of the local cultural heritage, the implementation of cultural heritage protection at the national level alone will not fully solve the problem. Especially in the present day when a large amount of manpower and material resources are required to be protected, system protection for cultural heritage cannot be achieved by relying solely on the power of one country. In this case, it is necessary to extract the essence of cultural heritage from around the world to include the common heritage [5]. It is protected inside. At the same time, it stipulates that such cultural heritage is in conformity with certain standards, that is, a cultural heritage that is representative in the field and is of irreplaceable importance to people of all nationalities. Only in this way can a law be protected as a common heritage. Status, through the implementation of international cooperation, etc., in the international community to provide assistance in the protection of these cultural heritage. It can be said that the Convention aims to provide collective assistance to the international community for a cultural heritage of significant universal value, recognize and protect the world cultural heritage of special significance. The convention establishes a list of heritage protection, establishes funds and other measures, and makes efforts to provide the international protection actions it promised.

\section{CONTENTS OF THE WORLD HERITAGE CONVENTION}

First, it clearly stated the criteria for the identification of world cultural heritage. The connotation of the world cultural heritage in the Convention is limited to the analysis of unique architectural buildings, heritage sites and cultural relics that have unique universal values and cannot be replaced by other cultural resources in the light of scientific, historical and artistic perspectives. The Convention specifies in detail which criteria a cultural heritage can be classified as a world cultural heritage, and which is based on a distinctive universal value cultural heritage with certain historical characteristics and sufficient protection measures. In addition to assuming their own responsibility to protect the world's cultural heritage, States parties should also take active and effective measures to protect other cultural heritage in their territories. It stipulated that the World Heritage Committee shall be responsible for the implementation of the Convention. Its rights include the decision to include the cultural heritage on the World Heritage List and decide on international aid actions. At the same time, the content of international aid operations is also stipulated.

As one of the important measures for the protection of the world's cultural heritage, it involves a large number of subjects and needs coordination among all parties, or national or international organizations or the public. Therefore, the initiation of international assistance should meet certain conditions and forms. It is stipulated in the convention that applying for international assistance should include the following content. First, the State party will apply on the basis of a reasonable cause, combine the status of the legacy with the study of the World Heritage Committee, consult with the representatives of the State Party, experts and technical personnel, and demonstrate the necessity of international assistance, and make a final decision. Decided to take aid actions, including support for financial assistance, technical equipment support, provision of business training, and assignment of experts in the contents of the aid operations.

Secondly, some of the principles and provisions stipulated in the Convention need to be combined with a series of supporting measures such as the "Implementation of the World Heritage Convention Operation Guide" to provide reference for practical activities. Former World Heritage Center Chairman Francesco Bandarin mentioned in his article on the protection of world cultural heritage at the time that the Convention has for the past three decades been committed to expanding the scope of the protection of world cultural heritage to encompass the many cultural heritages that exist on Earth. As a predictable and effective legal tool, the Convention is built on the following premise: Because parts of the Earth have significant universal value due to their natural, spiritual, or historical civilization, protecting these important areas cannot be a simple division. Responsibility for a country should be the common mission of the international community.

Thirdly, the Convention has enriched the scope of protection of the world's cultural heritage. In the past, the protection of cultural heritage only evolved from the single protection model under a certain framework to the scope of protection identified, preserved, exhibited and passed down by the Convention. , universality, systematic protection. The scope of protection of the Convention and the scope of traditional protection are limited to the extension of the partial scope involved in a given situation. At the same time, the cultural heritage and the natural heritage are collectively listed as objects of protection, and the quantity between the two is balanced to highlight the harmonious relationship between humans and the environment. Environmental protection concept. The Convention abandons the past provisions on the protection of certain conditions and provides comprehensive protection of cultural heritage environmental issues caused by human factors and natural factors.

Fourth, the Convention further emphasizes the national responsibility for the protection of cultural heritage in terms of protection measures. The stipulated countries should be equipped with appropriate regulatory agencies, with their protection obligations in the fields of administration, legislation, science, finance, education, etc., and at the same time, stipulate measures such as registration and delisting of world cultural heritage, periodic reports, state supervision, and international assistance, from the state responsibility. The specific protection measures adopted will make the Convention more effective, operational, and authoritative, and it will contribute to the protection, display, and inheritance of the world's cultural heritage.

The promulgation of the convention provides a legal basis for establishing the protection status of the world's cultural heritage in international law and clarifies the purpose and mechanism for the protection of cultural heritage in the form of legislation. It has a very important role in the demonstration of national heritage protection in all countries of the world.

\section{REFERENCES}

[1] UNESCO. 2016. Decisions adopted by the World Heritage Committee at its $40^{\text {th }}$ session, session of the Committee. http://whc.unesco.org/en/sessions/40com/.

\section{[2] http://whc.unesco.org/en/list.}

[3] http://whc.unesco.org/en/conventiontext.

[4] Blake, J. 2000. On Defining Cultural Heritage. International and Comparative Law Quarterly, 49 (1).

[5] Francioni, F. 2002. Thirty Years On: Is The World Heritage Convention Ready for 21st Century?XII Italian Yearbook of International Law, 13. 